\title{
SENSOR KIMIA UNTUK MENDETEKSI ASPARTAM MENGGUNAKAN REAGEN NINHIDRIN TERIMOBILISASI
}

\section{Chemical Sensor To Detect Aspartame With Immobilized Ninhydrin Reagen}

\author{
Muhammad Bakhru Thohir*, Ni'matus Sabila \\ Program Studi Kimia, Fakultas Sains dan Teknik, Universitas Bojonegoro, Bojonegoro \\ email: muhammadbakhru@gmail.com
}

\begin{abstract}
Abstrak. Aspartam adalah salah satu bahan tambahan makanan yang sering digunakan sebagai pemanis untuk minuman. Penggunaan aspartam dibatasi karena dapat memicu mundulnya penyakit phenylketonuria. Sensor kimia sederhana untuk mendeteksi aspartam pada minuman kemasan dengan reagen ninhidrin telah dilakukan. Percobaan dilakukan dengan tahapan penentuan kondisi optimum, pembuatan kurva standar, pembuatan sensor dengan metode sol-gel, pembuatan deret intensitas warna bentuk larutan dan sensor sederhana serta uji pada sampel buatan dan minuman kemasan. Hasil penelitian ini adalah panjang gelombang optimum reaksi aspartam dan ninhidrin yakni 569,0 nm, pH optimum reaksi 5 dan konsentrasi optimum 1:2,1. Deret intensitas warna semakin pekat pada konsentrasi yang lebih besar. Kurva standar mendapatkan persamaan regresi y $=0,8507 x-$ 0,1242 dengan $\mathrm{R}^{2}=0,9715$. Sensor memunculkan warna orchid (turunan warna ungu dengan nilai RGB: 194107 186). Pengujian sampel buatan menunjukan konsentrasi aspartam sebesar 0,0006 $\mathrm{M}$ dan sampel minuman kemasan sebesar 0,0018 M setelah dikonfirmasi dengan deret intensitas warna.
\end{abstract}

Kata Kunci: aspartam; ninhidrin; sensor kimia; sol-gel; TEOS

Abstract. Aspartame is a food additive that is often used as a sweetener for drinks. The use of aspartame is limited because it can trigger the spread of phenylketonuria. Simple chemical sensor for detection of aspartame in packaged drinks with ninhydrin reagent has been done. The experiment was carried with the stage of determining the optimum conditions, making the standard curve, creating the sensor with the sol-gel method, making the series of colors intensity in a solution and a simple sensoring and testing on both artificial sample and packaged beverage. The results of this research was the optimum wave length of the aspartame and ninhydrin reaction was $569.0 \mathrm{~nm}$, the optimum $\mathrm{pH}$ of the reaction was 5 and the optimum concentration was 1: 2.1. The series of color intensity progressively densed on larger concentration. The standard curve obtained the regression equation $y=0.8507 x-0.1242$ with $R^{2}=0.9715$. The Sensor brought out the orchid color (derivative purple with RGB value: 194107 186). The testing of simulation sample indicated that the concentration of aspartame was 0,0006 $M$ and the sample of packaged beverage was 0,0018 $\mathrm{M}$ after being confirmed with the series of color intensity.

Keyword: aspartame; ninhydrin; chemical sensor; sol-gel; TEOS 


\section{PENDAHULUAN}

Makanan saat ini baik yang ditemukan di toko modern atau tradisional tidak lagi semuanya aman dikonsumsi karena sudah banyak makanan yang mengandung zat aditif. Meningkatnya penambahan zat aditif dikarenakan saat ini sudah banyak ditemukan senyawa-senyawa baru yang dapat menjadi pemanis, pewarna, pengawet makanan (Winarno, 1992).

Penggunaan zat aditif dalam makanan sangat menguntungkan para pelaku usaha makanan, karena akan meminimalisir modal pengeluaran. Namun zat aditif apabila dikonsumsi terlalu banyak dan melebihi ambang batas aman akan berbahaya bagi kesehatan. Zat aditif akan terakumulasi dalam tubuh apabila terlalu sering digunakan, dan akan menimbulkan berbagai penyakit kronis seperti kanker dan keterbelakangan mental (Yunus, 2011). Beberapa jenis zat aditif yang beredar di masyarakat seperti asam benzoat, aspartam dan rhodamin B.

Aspartam adalah zat aditif jenis pemanis makanan. Penggunaan aspartam pada produk minuman sangat menguntungkan pengusaha minuman, karena bisa memotong pengeluaran dalam membeli pemanis. Aspartam memiliki tingkat manis 200 kali lipat dari gula sukrosa (Cahyadi, 2009). Konsumsi aspartam terlalu banyak akan menyebabkan munculnya penyakit kronis pada otak, antara lain gangguan neurologis, hal ini dikarenakan aspartam akan mengakibatkan munculnya senyawa radikal di otak. Senyawa radikal ini akan memicu tumbuhnya penyakit Phenylketonuria (PKU) (Ashok \& Rathinasamy, 2014).

Penggunaan aspartam tidak dilarang oleh Badan Pengawas Obat dan Makanan (BPOM) namun harus sesuai aturan Acceptable Daily Intake (ADI). Batas pengunaan aspartam pada makanan adalah $50 \mathrm{mg} / \mathrm{kg}$ berat badan sesuai surat edaran BPOM nomor KH.00.01.234.084 tanggal 11 Agustus 2006.

Analisis kadar aspartam dalam makanan sampai saat ini dilakukan dengan KLT dan KCKT (Yusuf \& Fatimah, 2013), kedua metode ini mahal, sulit dan rumit apabila harus dilakukan oleh masyarakat, sehingga perlu dibuat sebuah alat yang dapat menginterpretasikan jumlah aspartam di sebuah makanan yang dapat dilakukan secara langsung oleh masyarakat. Seperti yang dilakukan Prabowo, dkk. (2011) yang telah membuat sebuah sensor pendeteksi rhodamin B dalam makanan dengan reagen $\mathrm{Zn}(\mathrm{CSN})_{2}$ (Prabowo, 2011).

Pembuatan metode analisis dengan sensor juga sesuai dengan 12 prinsip kimia hijau yang dicetuskan Anastas dan Warner pada 1998, karena akan memangkas penggunaan bahan kimia, energi, dan waktu oprasinal (deMarco, Rechelo, Totoli, C, \& $\mathrm{N}, 2018$ ). Beberapa jenis sensor kimia antara lain menggunakan prinsip kolorimetri dan elektrokimia. Analisis kolorimetri berdasarkan pada perubahan warna suatu bahan akibat terjadinya reaksi kimia, umumnya terjadi pada medium cair (Gilchrist \& Nobbs, 2017), namun kondisi ini bisa dimodifikasi menjadi sensor dengan melakukan imobilisasi (Mizuguchi, Zhang, Onedera, Nishizawa, \& Shida, 2008).

Imobilisasi adalah sebuah tahapan yang penting dalam pembuatan sensor. Teknik imobilisasi yang benar akan memberikan kualitas yang baik pada sensor dan imobilisasi menentukan bekerja atau tidaknya reagen yang digunakan dalam sensor. Jenis-jenis imobilisasi sangat banyak antara lain bisa dilakukan dengan cara polimerisasi (Moersilah, Dwi, Roto, \& Mudasir, 2017), silika gel (Shahamirifard, 2018), beads (Susanto, 2015), dan kertas selulosa (Kong \& Ni, 2009). Dalam penelitian ini akan 
dibuat sensor dengan metode imobilisasi mengunakan teknik sol-gel seperti yang dilakukan dalam membuat sensor glukosa (Nur, Wahyu, Yeni, \& Heru, 2010) dan sensor gas (Widodo, 2010).

Teknik imobilisasi dengan silika gel juga memiliki banyak jenis, semisal dengan media kertas saring atau dengan kaca (Samadi-Maybodi, Rezaei, \& Rastegaezadeh, 2015). Sementara itu, performa yang dihasilkan dengan melakukan imobilisasi reagen pada silika gel dengan teknik sol-gel tergolong sangat bagus (Shahamirifard dkk., 2018). Aplikasi dari sensor kimia sampai saat ini umumnya digunakan untuk mendeteksi gas rumah kaca (Widodo, 2010), logam berbahaya (Shahamirifard dkk., 2018), dan bahan yang beracun (Moersilah, Dwi, Roto, \& Mudasir, 2017), sementara pembuatan sensor untuk bahan tambahan makanan yang sering ditemui di kehidupan sehari-hari masih jarang dieksplorasi, sehingga dari sana menjadi penting melakukan pembuatan sensor untuk zat aditif yang sering digunakan, termasuk diantaranya adalah aspartam. Dan yang menjadi sangat penting adalah aspartam banyak digunakan untuk produk yang dikonsumsi anak-anak, sementara efek samping aspartam adalah pada sistem neurologis otak.

Pada penelitian ini akan dibuat pendeteksi berupa sensor kimia yang sederhana dengan cara mengimobilisasi reagen ninhidrin, sensor kimia ini akan mendeteksi zat aditif aspartam pada minuman kemasan. Reaksi yang terjadi akan mengubah aspartam yang semula berwarna bening menjadi ungu dan membentuk persenyawaan imina dengan gugus fungsi ketimina sekunder (RC(=NR")R') (Friedman, 2004). Teknik imobilisasi yang digunakan adalah teknik entrapmen, metode yang digunakan dalam membentuk sensor ini adalah dengan sintesis sol-gel dengan prekusor tetraetilortosilika (TEOS).

\section{METODE PENELITIAN Alat dan Bahan}

Alat yang digunakan adalah gelas kimia, pipet, gelas arloji, stirer, magnet stirer, spatula, corong dan loyang untuk mencetak sensor. Sementara, instrumen yang digunakan adalah spektrofotometer UV-Vis Varian cary 50 conc.

Bahan yang digunakan pada penelitian ini terdiri dari aspartam $\left(\mathrm{C}_{14} \mathrm{H}_{18} \mathrm{~N}_{2} \mathrm{O}_{5}\right)$ Food Grade, ninhidrin p.a. $\left(\mathrm{C}_{9} \mathrm{H}_{6} \mathrm{O}_{4}\right)$ (Merck), aquades, aquabides, buffer asetat $\mathrm{pH} 2 ; 3 ; 4 ; 5$, buffer phosfat pH 6; 7, tetraetil ortosilika p.a. $\left(\mathrm{Si}\left(\mathrm{OC}_{2} \mathrm{H}_{5}\right)_{4}\right)\left(\right.$ Merck), etanol p.a. $\left(\mathrm{C}_{2} \mathrm{H}_{6} \mathrm{O}\right)$ dan sampel minuman kemasan yang mengandung aspartam.

\section{Langkah Penelitian}

Menentukan panjang gelombang optimum dilakukan pada 470-800 nm, pH optimum dari 2-7 dan konsentrasi optimum perbandingan aspartam $1 \mathrm{~mL}$ dengan ninhidrin 0,$6 ; 0,9 ; 1,2 ; 1,5 ; 1,8 ; 2,1 ; 2,4 \mathrm{~mL}$. Selanjutnya dibuat kurva standar aspartamninhidrin.

Pembuatan sensor dilakukan dengan mencampurkan $3 \mathrm{~mL}$ aquades, $6 \mathrm{~mL}$ TEOS, dan 6,0 mL etanol 98\%. Komposisi campuran ini distirer hingga homogen selama 20 jam tanpa pemanasan sampai berfasa gel. Hasil dituangkan pada kertas saring pada loyang dan dikeringkan semalam (Prabowo, 2011).

Selanjutnya dibuat deret warna berbentuk larutan dan sensor sederhana pada rentang konsentrasi 0,$0006 ; 0,0012 ; 0,0018 ; 0,0024 ; 0,0030 \mathrm{M}$. Yang terakhir adalah uji 
sampel aspartam standar dan aspartam dari minuman kemasan. Aspartam diteteskan pada sensor dan disamakan dengan deret warna untuk menginterpretasi kadarnya. Data yang didapat dianalisis dengan analisis statistik rancangan acak lengkap (RAL) analisis variasi satu arah.

\section{HASIL PENELITIAN DAN PEMBAHASAN \\ Penentuan Kondisi Optimum}

Hasil penentuan panjang gelombang di tunjukan pada Gambar 1. Muncul puncak absorbansi maksimal pada daerah panjang gelombang 569,0 nm, serapan ini dihasilkan dari hasil reaksi antara aspartam dengan ninhidrin. Serapan dihasilkan dari penambahan auksokrom pada kromofor yang akan menggeser panjang gelombang ke daerah yang lebih yang lebih lebar. Hal ini ditandai dari, baik aspartam dan ninhidrin, sama-sama tidak berwarna, kemudian berubah menjadi ungu setelah direaksikan. Panjang gelombang 569,0 nm memiliki warna komplementer nila (turunan warna ungu dengan nilai RGB: 862 140) dan ini menunjukan bahwa absorbansi yang muncul adalah milik hasil reaksi antara aspartam dan ninhidrin (Effendy, 2011).

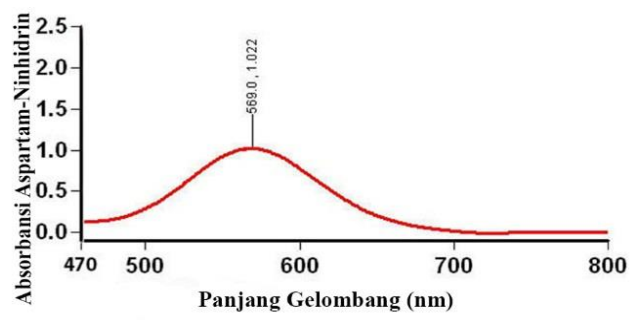

Gambar 1. Spektran UV-Vis pengukuran panjang gelombang optimum hasil reaksi aspartam dan ninhidrin

Pada penentuan $\mathrm{pH}$ optimum didapat sebuah data hasil absorbasi yang ditunjukkan pada Tabel 1. Data yang didapat dihitung menggunakan analisis variasi satu arah metode rancangan acak lengkap (RAL), dan hasil tabel ANOVA di tunjukan pada Tabel 2.

Tabel 1. Data absorbansi pengukuran pH optimum

\begin{tabular}{|c|c|c|c|c|c|}
\hline \multirow[t]{2}{*}{ pH } & \multicolumn{4}{|c|}{ Perlakuan } & \multirow{2}{*}{ Total } \\
\hline & I & II & III & IV & \\
\hline 2 & 0,0058 & 0,0064 & 0,0068 & 0,0058 & 0,0251 \\
\hline 3 & 0,0646 & 0,0876 & 0,0705 & 0,0595 & 0,2822 \\
\hline 4 & 0,2635 & 0,2642 & 0,3216 & 0,2882 & 1,1375 \\
\hline 5 & 0,2232 & 0,3949 & 0,3250 & 0,3098 & 1,2529 \\
\hline 6 & 0,1805 & 0,3739 & 0,3298 & 0,3132 & 1,2032 \\
\hline \multirow[t]{2}{*}{7} & 0,2146 & 0,3192 & 0,3693 & 0,3261 & 1,2292 \\
\hline & & & & & 5,1301 \\
\hline
\end{tabular}


Tabel 2. Tabel ANOVA pengukuran pH optimum

\begin{tabular}{ccccc}
\hline $\begin{array}{c}\text { Sumber } \\
\text { keragaman }\end{array}$ & Db & Jk & Kt & F Hitung \\
\hline Perlakuan & 5 & 0,379058 & 0,075811 & 26,120551 \\
Galat Percobaan & 18 & 0,052242 & 0,002902 & \\
Total & 23 & 0,431301 & & \\
\hline
\end{tabular}

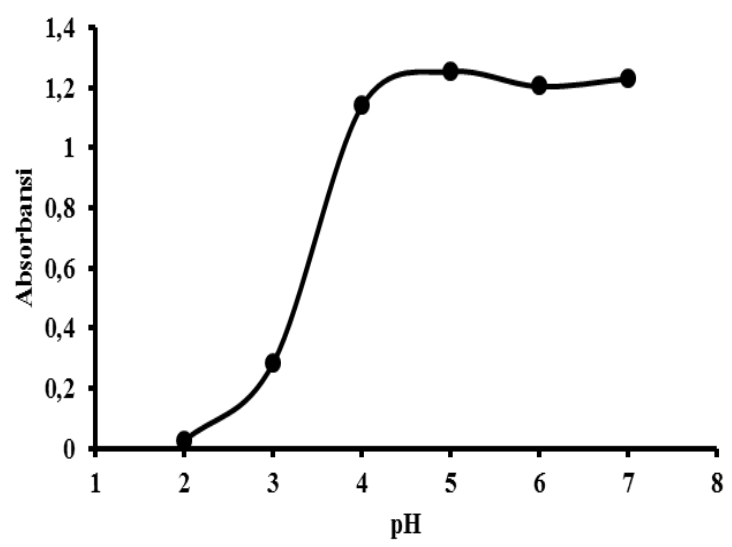

Gambar 2. Kurva pH optimum hasil reaksi antara aspartam dan ninhidrin

Data pada Tabel 2 kemudian dicocokkan dengan data yang ada pada $\mathrm{F}$ tabel. $\mathrm{F}$ Tabel untuk $\alpha$ 0,05 adalah 2,77. Sehingga F Hitung $>$ dari F tabel, hasil ini berarti bahwa percobaan yang dilakukan adalah menolak $\mathrm{H}_{0}$. Kesimpulan yang dapat ditarik dari uji tahap ini adalah $\mathrm{pH}$ berpengaruh secara signifikan pada hasil absorbansi. Kurva uji perbedaan $\mathrm{pH}$ terhadap hasil absorbansi ditunjukkan pada Gambar 2. $\mathrm{pH}$ optimum berada di nilai 5 yang menunjukan bahwa kondisi yang diperlukan ninhidrin dalam mendeteksi aspartam adalah di $\mathrm{pH}$ cukup asam. Hal ini sesuai dengan sifat aspartam yang sedikit asam dan peruntukannya untuk minuman dengan rasa manis-asam. Berdasarkan data pada Gambar 2 kemudian dapat ditarik sebuah hasil bahwa dalam melakukan analisis pada aspartam menggunakan ninhidrin, kondisi $\mathrm{pH}$ terbaiknya adalah 5.

Kondisi optimum reaksi juga sangat berpengaruh pada tahap analisis, hal ini dikarenakan $\mathrm{pH}$ juga menjadi faktor yang penting pada sintesis sol-gel (Brinker \& Scherer, 1990). Setiap pH memiliki karakteristik yang khas pada hasil sol-gel, selain itu penentuan $\mathrm{pH}$ juga akan memaksimalkan proses deteksi, seperti yang dilakukan pada penentuan tembaga (Shahamirifard dkk., 2018).

Pada penentuan konsentrasi optimum didapat sebuah data hasil absorbasi yang ditunjukkan pada Tabel 3. Hasil analisis variasi 1 arah model rancangan acak lengkap (RAL) pada tahap ini di tunjukan pada Tabel 4. Data pada Tabel 4. dilakukan uji signifikansi dengan mencocokkan hasilnya pada $\mathrm{F}$ tabel. F Tabel untuk $\alpha 0,05=2,57$. Hasil yang didapat menunjukkan bahwa F Hitung $>$ F tabel dan hasil percobaan ini 
Dalton : Jurnal Pendidikan Kimia dan Ilmu Kimia, Volume 4 Nomor 1, Mei 2021

memiliki arti menolak $\mathrm{H}_{0}$ atau konsentrasi berpengaruh secara signifikan pada hasil absorbansi. Kurva perbandingan antara konsentrasi dengan absorbansi yang terbentuk ditunjukan pada Gambar 3.

Tabel 3. Data absorbansi pengukuran konsentrasi optimum

\begin{tabular}{cccccc}
\hline Konsentrasi & \multicolumn{3}{c}{ Ulangan } & Total \\
\cline { 2 - 6 } & 1 & 2 & 3 & 4 & \\
\hline$(0,6 \mathrm{~mL})$ & 0,4513 & 0,4280 & 0,3357 & 0,4736 & 1,6886 \\
$(0,9 \mathrm{~mL})$ & 0,5128 & 0,4423 & 0,4230 & 0,4979 & 1,8760 \\
$(1,2 \mathrm{~mL})$ & 0,5317 & 0,4652 & 0,4526 & 0,5759 & 2,0253 \\
$(1,5 \mathrm{~mL})$ & 0,5628 & 0,5200 & 0,5154 & 0,5797 & 2,0254 \\
$(1,8 \mathrm{~mL})$ & 0,6506 & 0,5288 & 0,5625 & 0,7129 & 2,4548 \\
$(2,1 \mathrm{~mL})$ & 0,6952 & 0,6431 & 0,7446 & 0,7327 & 2,8155 \\
$(2,4 \mathrm{~mL})$ & 0,4708 & 0,4028 & 0,4932 & 0,5481 & 1,9149 \\
Total & 3,8752 & 3,4302 & 4,5270 & 4,1207 & 14,9531 \\
\hline
\end{tabular}

Tabel 4. Tabel ANOVA pengukuran konsentrasi optimum

\begin{tabular}{lcccc}
\hline Sumber keragaman & db & Jk & Kt & F Hitung \\
\hline Perlakuan & 6 & 0,233471 & 0,037245 & 11,53516 \\
Galat Percobaan & 21 & 0,067806 & 0,003229 & \\
Total & 27 & 0,301277 & & \\
\hline
\end{tabular}

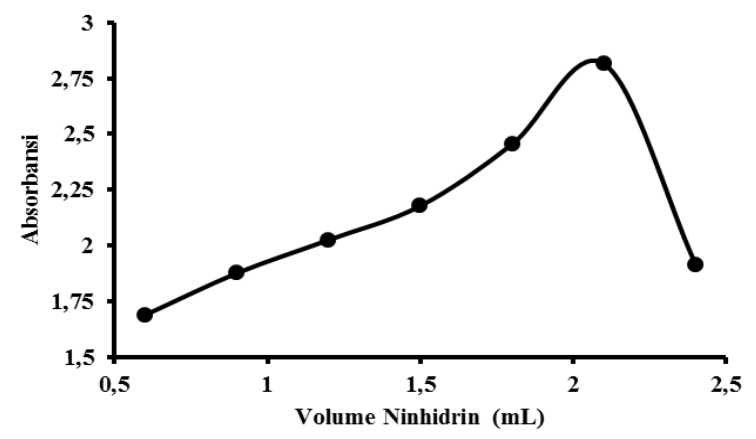

Gambar 3. Kurva konsentrasi optimum hasil reaksi antara aspartam dan ninhdirin 


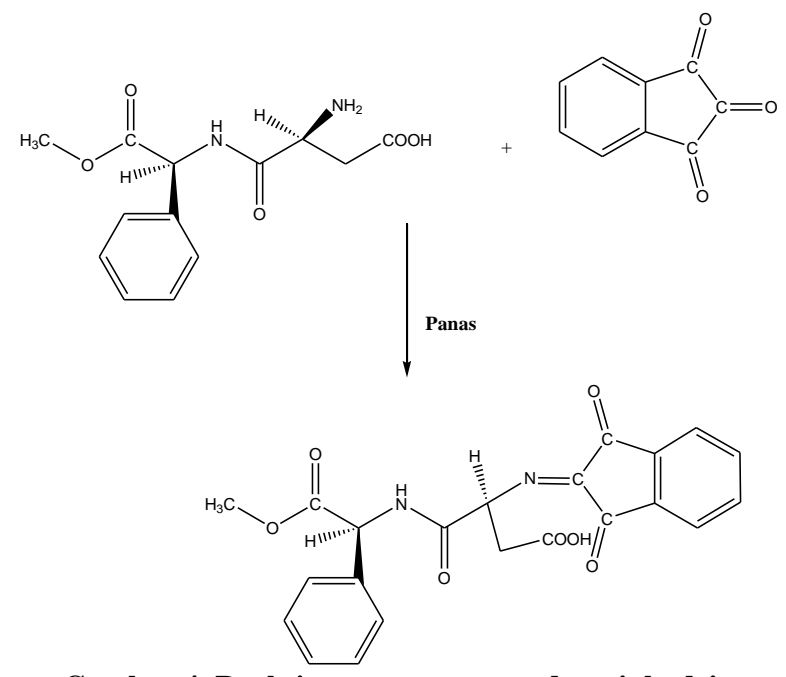

Gambar 4. Reaksi antara aspartam dan ninhydrin

Perbandingan antara konsentrasi yang optimum untuk analisa aspartam dengan ninhidrin yang ditunjukkan Gambar 3 adalah 1,0 mL aspartam $(0,03 \mathrm{M})$ dengan 2,1 mL ninhidrin $(0,03 \mathrm{M})$. Kesimpulan yang dapat diambil pada tahap ini adalah perbandingan terbaik untuk melakukan analisa aspartam adalah 1:2,1. Perbandingan optimum yang dihasilkan setara dengan reaksi antara aspartam dan ninhidrin yang ditunjukkan pada Gambar 4. Nilai konsentrasi optimum juga akan menjadi acuan dalam penentuan konsentrasi aspartam yang ada di sampel dengan penentuan secara penbandingan stoikiometri.

Setelah selesai menentukan kondisi optimum, kemudian dilanjutkan pada tahapan pemuatan kurva standar. Dilakukan dengan mengukur absorbansi yang dihasil dari reaksi antara aspartam 0,$1 ; 0,2 ; 0,3 ; 0,4 ; 0,5 ; 0,6 ; 0,7 ; 0,8 ; 0,9 ; 1,0 \mathrm{~mL}$ dengan $1,0 \mathrm{~mL}$ ninhidrin. Semua kondisi pada pembuatan kurva standar disesuaikan dengan hasil-hasil yang telah didapat pada percobaan sebelumnya. Hasil pengukuran absorbansi ditampilkan pada Gambar 5.

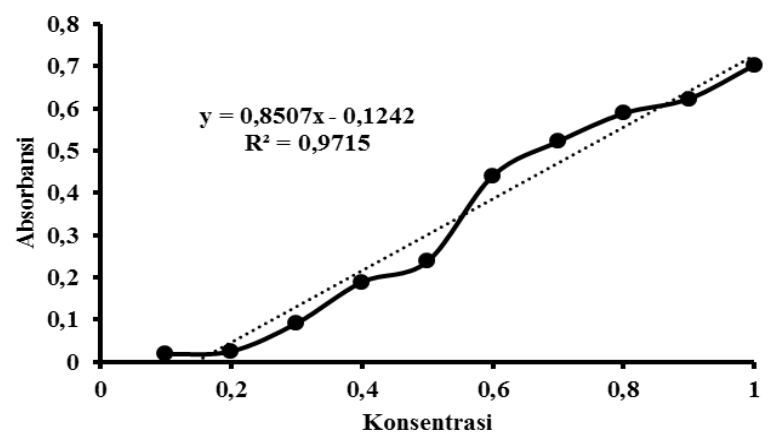

Gambar 5. Kurva standar aspartam dan ninhidrin 


\section{Pembuatan Sensor Kimia Sederhana}
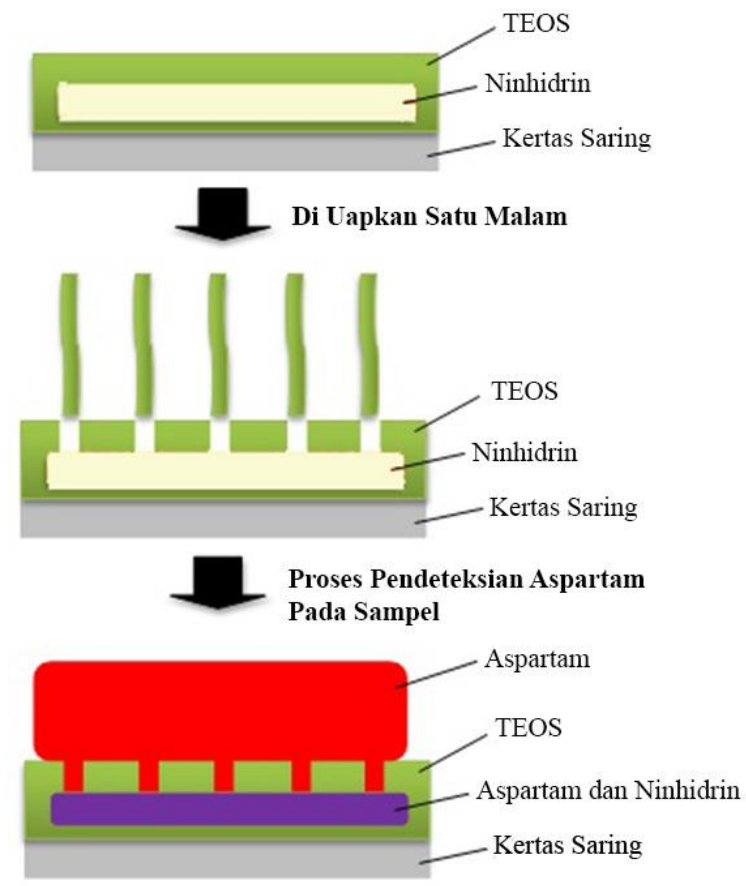

Gambar 6. Ilustrasi kerja sensor

Proses sintesis silika gel dengan jalan sol-gel dapat dibedakan menjadi dua; yakni homogen dan heterogen. Perbedaan antara dua metode ini adalah penggunaan pelarut etanol, sistem homogen menggunakan etanol dan akan menghasilkan silika gel dalam bentuk kental, sementara metode heterogen tanpa melibatkan alkohol dan akan didapatkan hasil yang kering (Stanley \& Nesaraj, 2014). Sensor kimia yang disintesis dengan metode sol-gel lebih prever mengunakan metode homogen karena lebih mudah diatur dan diletakkan dalam media solit padat. Hasil dari perlakuan ini adalah larutan bening dengan semua bahan tercampur setelah penambahan etanol. Proses hidrolisis memerlukan waktu selama selama $20 \mathrm{Jam}$. Hal ini dikarenakan sol-gel yang digunakan pada penelitian ini tidak menggunakan katalis.

Proses hidrolisis TEOS oleh aquabides seperti reaksi berikut (Fernandez, 2012):

$$
\mathrm{Si}(\mathrm{OR})_{4}+\mathrm{xH}_{2} \mathrm{O} \rightarrow(\mathrm{OH})_{\mathrm{x}} \mathrm{Si}(\mathrm{OR})_{4-\mathrm{x}}+\mathrm{xROH}
$$

Setelah proses hidrolisis, kemudian terjadi proses kondensasi:

Kondensasi alkohol

Kondensasi air

$$
\mathrm{Si}(\mathrm{OR})_{4}+(\mathrm{OH}) \mathrm{Si}(\mathrm{OR})_{3} \rightarrow(\mathrm{OR})_{3} \mathrm{Si}-\mathrm{O}-\mathrm{Si}(\mathrm{OR})_{3}+\mathrm{ROH}
$$

$$
(\mathrm{OR})_{3} \mathrm{Si}(\mathrm{OH})+(\mathrm{OH}) \mathrm{Si}(\mathrm{OR})_{3} \longrightarrow(\mathrm{OR})_{3} \mathrm{Si}-\mathrm{O}-\mathrm{Si}(\mathrm{OR})_{3}+\mathrm{H}_{2} \mathrm{O}
$$


Setelah proses kondensasi, dilanjutkan dengan tahap pematangan (aging) yang mengubah fasa dari sol menjadi gel. Dalam tahap kondensasi cairan menjadi lebih kental dan keruh. Secara garis besar, tahapan sintesis sol-gel dimulai dengan prepatasi sol, gelation, aging, dan pengeringan. Lama dan sebentarnya sintesis bergantung pada penggunaan katalis (Du, Zhou, Zhang, \& Shen, 2013).

Gel yang didapat dicetak di media kertas saring dan didiamkan semalam agar menguapkan etanol dan air sehingga akan membuka pori yang nantinya akan digunakan sebagai jalan masuk sampel untuk bereaksi dengan reagen. Setelah sol-gel kering, kemudian dipotong-potong dengan ukuran $1 \times 1 \mathrm{~cm}$ dan ditempelkan pada kertas foto sehingga menyerupai $\mathrm{pH}$ universal. Kinerja dari sensor kimia yang dibuat diilustrasikan pada Gambar 6. Sampel akan masuk melewati pori-pori yang terdapat pada permukaan silika gel hasil pengeringan, dan proses kolorimetri terjadi di celah-celah silika gel yang telah menimobilisasi ninhindrin.

Hasil percobaan didapatkan silika gel yang agak kering dan mudah pecah ketika diperlakukan dengan kasar, hal ini adalah ciri dari sol-gel yang disintesis dengan cara heterogen. Salah satu keungulan dari sol-gel heterogen adalah mudahnya diuapkan, akan tetapi hasilnya perlu penanganan yang hati-hati, sementara sol-gel homogen lebih lambat menguap tetapi hasilnya lunak (Dervin \& Pillai, 2017).

\section{Pembuatan Deret Warna dan Pengujian Sampel}

Selepas pembuatan sensor dengan metode sol-gel, tahap selanjutnya adalah membuat deret intensitas warna dalam fasa larutan dan solid (sensor kimia). Deret warna dalam bentuk cairan ditunjukkan pada Gambar 7. Sementara deret warna dalam bentuk sensor kimia ditunjukkan pada Gambar 8.

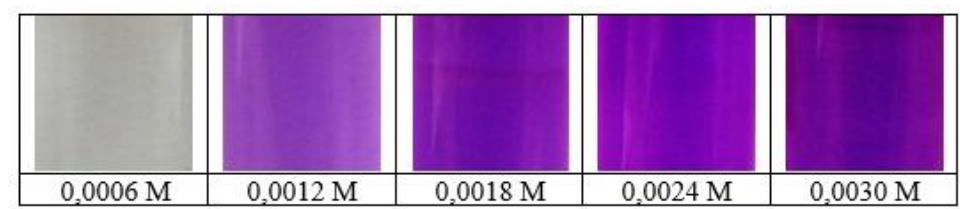

Gambar 7. Deret warna bentuk larutan

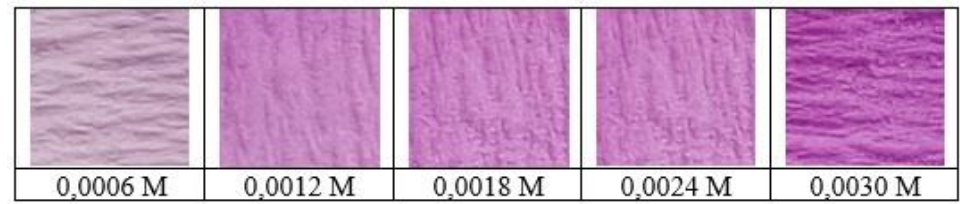

Gambar 8. Deret warna bentuk sensor kimia sederhana

Deret intensitas warna yang dibuat nantinya akan digunakan sebagai uji semi kuantitatif dalam menentukan kadar aspartam pada minuman kemasan dan juga aspartam standar. Hasil pengujian pada sampel aspartam standar ditunjukan pada Gambar 9. Warna yang terbentuk pada sensor setelah dikontakkan dengan sampel buatan dicocokan dengan deret warna standar yang sudah dibuat. Warna dari sampel buatan berada di daerah 0,0006 M. Warna orchid (turunan warna ungu dengan nilai RGB: 194107 186) terbentuk secara merata di seluruh permukaan sensor. Sementara untuk hasil uji pada sampel dari minuman kemasan ditunjukkan pada Gambar 10. 


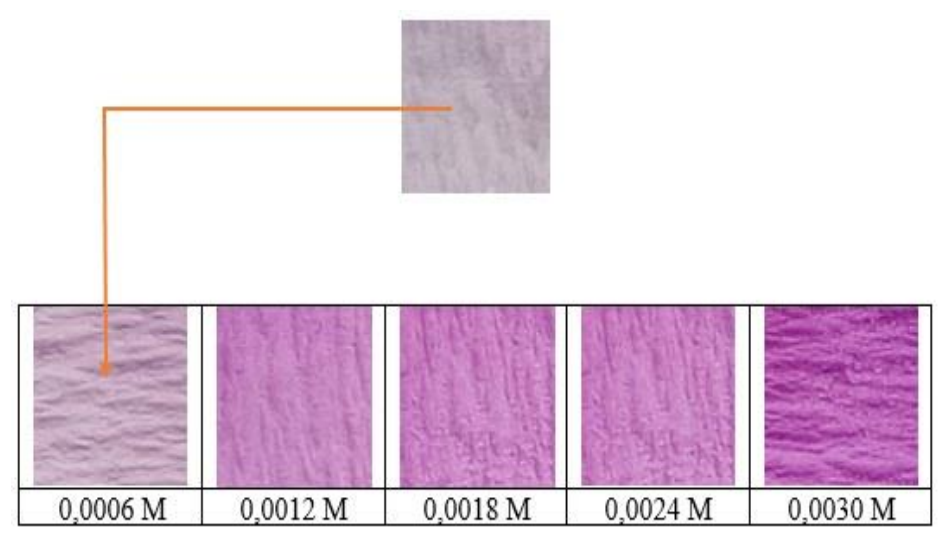

Gambar 9. Hasil analisa sampel buatan pada deret warna

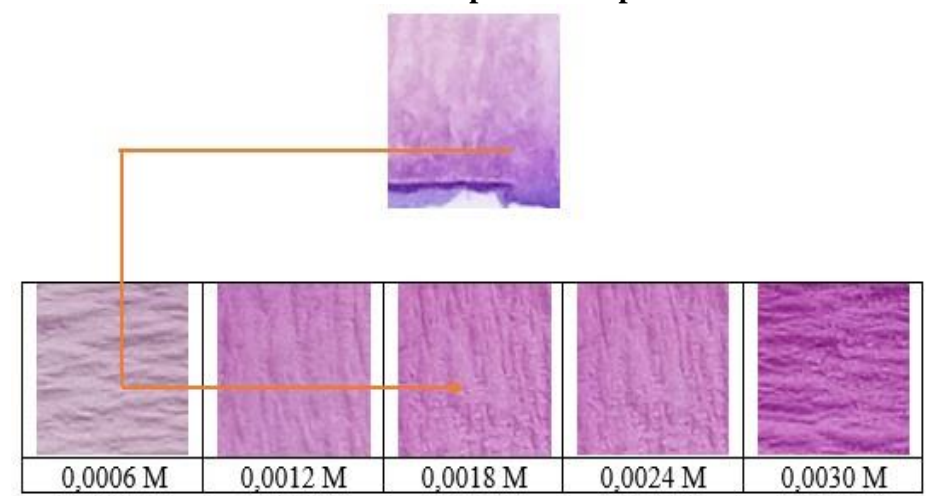

Gambar 10. Hasil analisa sensor pada sampel aspartam pada minuman kemasan

Hasil analisis pada sampel dari minuman kemasan menggunakan sensor tidak menunjukkan hasil yang sama dengan sampel buatan. Pada sampel dari minuman kemasan, warna yang terbentuk hanya keluar pada bagian tepi. Hal ini dikarenakan proses deteksi aspartam pada sampel tidak berjalan cukup maksimal, karena masih banyak matriks yang ikut terlibat dalam analisa, dan hal ini mengakibatkan hanya sedikit aspartam yang bertemu ninhidrin pada sensor, Namun, ketika dilihat dari warna yang muncul di tepi sensor, hasil deteksi menunjukkan konsentrasi aspartam pada minuman kemasan setara dengan 0,0018 M. Penentuan sampel dengan deret warna standar juga telah dilakukan oleh shahamirifard pada penentuan perak, fakta ini menunjukan bahwa penentuan semi kuantitatif bisa dilakukan dengan menggunakan deret warna standar (Shahamirifard dkk., 2018).

\section{SIMPULAN}

Hasil penentuan kondisi optimum reaksi antara aspartam dan ninhidrin adalah terbentuknya warna orchid dengan panjang gelombang $569.0 \mathrm{~nm}$, pH 5 dan dengan perbandingan konsentrasi 1:2,1 $\mathrm{mL}(0,03 \mathrm{M})$. Performa sensor kimia dalam mendeteksi sampel ditunjukkan dengan munculnya warna orchid pada sensor. Warna yang muncul 
adalah interpretasi terhadap jumlah aspartam, dapat dilakukan uji analisis kuantitatif dengan membandingkan hasil analisa dengan deret warna sensor.

\section{DAFTAR RUJUKAN}

Ashok, I., \& Rathinasamy, S. (2014). Biochemical Responses And Mitochondrial Mediated Activation of Apoptosis on Long-term Effect of Aspartame In Rat Brain. Redox Biology, 820-831.

Brinker, C. J., \& Scherer, G. W. (1990). Sol-gel science. San Diego: Academia Press.

Cahyadi, W. (2009). Analisis dan Aspek Kesehatan Bahan Tambahan Pangan edisi 2. Jakarta: Bumi Aksara.

deMarco, B. A., Rechelo, B. S., Totoli, E. G., C, K. A., \& N, S. H. (2018). Evolution of green chemistry and its multidimensional impacts: A review. SAUDI PHARM J, $1-8$.

Dervin, S., \& Pillai, S. C. (2017). An introduction to sol-gel proces sing for aerogels. Belanda: Springer.

Du, A., Zhou, B., Zhang, Z., \& Shen, J. (2013). A special material or a new state of matter: a review and reconsideration of the aerogel. J. Mater, 941-968.

Effendy. (2011). Kimia Koordinasi Jilid 1, Ed. 2. Malang: Indonesian Academic Publishing Indonesia.

Fernandez, R. B. (2012). Sintesis Nanopartikel SiO2 Menggunakan Metoda Sol-Gel dan Aplikasinya terhadap Aktifitas Sitotoksik Sel. Review Jurnal Nanopartikel, 5677.

Friedman, M. (2004). Application of the Ninhydrin Reaction for Analysis of Amino Acid, Peptides, and Proteins to Agricultural and Biomedical Science. Journal Agricultur Food Chemistry, 52, 385-406.

Gilchrist, A., \& Nobbs, J. (2017). Encyclopedia of Spectroscopy and Spectrometry, Edisi III. UK: University of Leeds.

Kong, F., \& Ni, Y. (2009). Development of cellulosic paper-based test strips for $\mathrm{Cr}(\mathrm{VI})$ determination. BioResources, 3, 1088-1097.

Mizuguchi, H., Zhang, Y., Onedera, H., Nishizawa, S., \& Shida, J. (2008). On-site determination of trace nickel in liquid sampeles for semiconductor manufacturing by highly sensitive solid-phase colorimetry with $\alpha$-furil dioxime. Chem. Lett, 37, 792-793.

Moersilah, Dwi, S., Roto, R., \& Mudasir, M. (2017). Optical chemical sensor of Cd(II) in water besed on 1-(2-pyridilazo)-2-napthol immobilized on poly(methyl methacrylate) and 2-nitrophenyl octyl ether matrix. MJAS, 21, 784-792.

Nur, A., Wahyu, D., Yeni, F., \& Heru, S. (2010). Immobilisasi Enzim Glucose Oxidase (GOD) dan Horse Radish Peroxidase (HRP) Untuk Aplikasi Biosensor dengan Metode Sol-Gel. Prosiding Seminar Rekayasa Kimia dan Proses (pp. 36-42). Semarang: Universitas Diponegoro.

Prabowo, I. E. (2011). Sensor Kimia Bentuk Stik Menggunakan Reagen Zn(CNS)2 Untuk Mendeteksi Rhodamin B Dalam Sampel Makanan. Surabaya: Skripsi Fakultas Sains dan Teknologi Universitas Airlangga.

Samadi-Maybodi, A., Rezaei, V., \& Rastegaezadeh, S. (2015). Sol-gel based optical sensor for determination of $\mathrm{Fe}$ (II): A novel probe for ion speciation. Spectrochim. Acta A, 136, 832-837. 
Dalton : Jurnal Pendidikan Kimia dan Ilmu Kimia, Volume 4 Nomor 1, Mei 2021

Shahamirifard, S. A., Ghaedi, M., \& Hajati, S. (2018). A new silver (I) ions optical sensor besed on nanoporous thin films of sol-gel by rose bengal dye. Sens. Actuator B-Chem, 259, 20-29.

Shahamirifard, S. A., Ghaedi, M., \& Montazerozohori, M. (2018). Design a sensitive optical thin film sensor based on incorporation of isonicotihohydrazide derivative in sol-gel matrix for determination of trace amounts of copper (II) in fruit juice: Effect of sonication time on immobilization approach. Ultrason Sonochem, 42, 723-730.

Stanley, R., \& Nesaraj, A. S. (2014). Effect of surfactants on the wet chemical synthesis of silica nanoparticles. Int. J. Appl. Sci. Eng, 1, 9-21.

Susanto, N. C. (2015). Pembuatan Beads i/k-Karaginan Sebagai Deteksi Kolorimetri Logam Fe Dengan Imobilisasi fenantrolin. Yogyakarta: Tesis Departemen Kimia FMIPA UGM.

Widodo, S. (2010). Teknologi Sol-Gel Dalam Pembuatan Nano Kristalin Metal Oksida Untuk Aplikasi Sensor Gas. Prosiding Seminar Rekayasa Kimia dan Proses (pp. 58-66). Semarang: Universitas DIponegoro.

Winarno. (1992). Kimia Pangan dan Gizi. Jakarta: Gramedia.

Yunus, M. (2011). Teknologi Pembuatan Asap Cair Dari Tempurung Kelapa Sebagai Pengawet Makanan. Jurnal Sains dan Inovasi, 54-61.

Yusuf, Y., \& Fatimah, N. (2013). Analisis Pemanis Buatan (Sakarin, Siklamat dan Aspartam) Secara Kromatografi Lapis Tipis Pada Jamu Gendong Kunyit Asam Diwilayah Kelapa Dua Wetan Jakarta Timur. Hasil Pengabdian Masyarakat, $50-55$. 